Article

\title{
Distribution Law of In Situ Stress and Its Engineering Application in Rock Burst Control in Juye Mining Area
}

\author{
Guangchao Zhang ${ }^{1,2}$, You Li ${ }^{1, *}$, Xiangjun Meng ${ }^{1,2}$, Guangzhe Tao ${ }^{1, *}$, Lei Wang ${ }^{3}$, Hanqing Guo ${ }^{2}$, Chuanqi Zhu ${ }^{3}$, \\ Hao Zuo ${ }^{1}$ and $\mathrm{Zhi} \mathrm{Qu}{ }^{1}$
}

check for

updates

Citation: Zhang, G.; Li, Y.; Meng, X.; Tao, G.; Wang, L.; Guo, H.; Zhu, C.; Zuo, H.; Qu, Z. Distribution Law of In Situ Stress and Its Engineering Application in Rock Burst Control in Juye Mining Area. Energies 2022, 15 1267. https://doi.org/10.3390/ en15041267

Academic Editors: Yulong Chen, Junwen Zhang, Jianhang Chen, Xuejie Deng and Manoj Khandelwal

Received: 30 December 2021

Accepted: 4 February 2022

Published: 9 February 2022

Publisher's Note: MDPI stays neutral with regard to jurisdictional claims in published maps and institutional affiliations.

Copyright: (C) 2022 by the authors. Licensee MDPI, Basel, Switzerland. This article is an open access article distributed under the terms and conditions of the Creative Commons Attribution (CC BY) license (https:// creativecommons.org/licenses/by/ $4.0 /)$.
1 College of Energy and Mining Engineering, Shandong University of Science \& Technology, Qingdao 266590, China; zgchao2015@163.com (G.Z.); mxjyx112@163.com (X.M.); zuohaocaikuang@163.com (H.Z.); qz13053574249@163.com (Z.Q.)

2 Shandong Energy Group Co., Ltd., Jinan 250014, China; tgzy112@163.com

3 State Key Laboratory of Mining Response and Disaster Prevention and Control in Deep Coal Mines, Huainan 232001, China; leiwang723@126.com (L.W.); zhuchuanqi2013@126.com (C.Z.)

* Correspondence: 201601010609@sdust.edu.cn (Y.L.); 201601010424@sdust.edu.cn (G.T.); Tel.: +86-156-1054-1030 (Y.L.); +86-178-5428-2741 (G.T.)

\begin{abstract}
This paper presents an integrated approach for mathematical statistics, theoretical analysis, and a field test to investigate the distribution law of in-situ stress and its engineering practice of rock burst control. The test site is located in the Juye mining area, Shandong Province, China. The main conclusions included: (1) There are two types of in-situ stress states in the Juye mining area, $\sigma_{H}>\sigma_{V}>\sigma_{h}(42.42 \%)$ and $\sigma_{H}>\sigma_{h}>\sigma_{V}(57.57 \%)$, which are mainly caused by the tectonic stress of the Heze and Fushan faults (The $\sigma_{H}, \sigma_{V}$, and $\sigma_{h}$ is the maximum principal stress, vertical principal stress or intermediate principal stress and minimum principal stress respectively). (2) The lateral pressure coefficients $K_{H}, K_{h}$, and $K_{a v}$ show a non-linear distribution with increased depth, approaching 1.32, 0.96 , and 1.41 , respectively. The variation range of the horizontal difference stress $\mu_{d}$ is $0.09-0.58$. (3) The average value of the stress gradient is $3.05 \mathrm{MPa} / 100 \mathrm{~m}$, and the main directions of the maximum horizontal principal stress are northeast-southwest, and northwest-southeast. (4) A new combined supporting strategy, incorporating optimization of roadway layout, anti-impact support system design, and local reasonable pressure relief, was proposed for the rock burst control, and its validity was verified via field monitoring. All these design principles and support strategies for the rock burst control presented in this study can potentially be applied to other similar projects.
\end{abstract}

Keywords: coal resources; coal mining; coal roadway support; Juye mining area; in-situ stress; rock burst; mining layout; high static stress; anti-impact support

\section{Introduction \\ 1.1. Research Background}

In-situ stress is the fundamental force that causes the deformation and failure of the surrounding rock in underground caverns, civil buildings, slopes, and other geotechnical engineering structures [1,2]. With the increase of the energy demand in China, coal mining has entered a state of deep mining [3]. Due to the higher mining intensity and the more complex distribution of in-situ stress, a large deformation of the deep roadway, damage of the support structure, and even rock burst and other disasters occur frequently [4,5]. A basic consensus has been reached in the mining industry that the prevention and control of disaster accidents related to underground coal mining should start with in-situ stress measurement and analysis [6,7].

To date, a number of studies have been conducted to investigate in-situ stress measurement methods and equipment, field measurement, and its distribution law in China. For example, Cai et al. [8] proposed a device for in-situ stress measurement based on complete temperature compensation, and further put forward the calculation method for in-situ 
stress. Kang et al. [9] presented a small-aperture hydraulic-fracturing in-situ stress measurement method and applied it in Luan, Jincheng, Fenxi, and other mining areas in China. Wang et al. [10] performed field monitoring to investigate the in-situ stress distribution law of the Ping-ding-shan mining area. Chen et al. [11] elaborated on the mechanism of rock burst in a deep roadway and developed a series of roadway anti-impact bolts, hydraulic supports, etc. Jiang et al. [12] established a variety of rock burst models in coal mines and summarized the characteristics, occurrence mechanism, and prevention technologies of rock burst disasters in China. All these studies have improved our understanding of the in-situ stress measurement and its relationships with the rock burst control.

It is well known that the distribution of in-situ stress is closely related to the geological structure, and exhibited evident regional distribution characteristics $[13,14]$. The Juye mining area, located southwest of Shandong Province, is currently the most important coalresource-producing area in Shandong Province. However, faults and folds are seriously developed, and the seismic activity is strong in this area. All these complex geological structures contribute to higher regional stress accumulation levels. Consequently, many rock burst accidents occurred in coal mines of the Juye mining area, resulting in a considerable number of casualties, extra labour, financial resources, and time loss. However, due to the lack of measured data, the relevant studies on the characteristics of the in-situ stress field and its correlation with rock burst disaster are very limited.

First of all, the roadway layout of most mines in the Juye mining area did not consider the influence of in-situ stress at the beginning. Secondly, with the increase of mining depth, some mines that did not have rock burst before also began to have rock burst. In addition, the current rock burst prevention and control system is not perfect, and some mines in the Juye mining area have an obvious lack of impact resistance. All this is due to our lack of a clear understanding of the in-situ stress field in the Juye mining area and a complete set of impact support systems. Therefore, we must systematically study the in-situ stress field in the Juye mining area. As stated at the beginning of the article, in-situ stress is the basic stress of all engineering disasters. Of course, this also includes rock burst disaster. By studying the stress field environment, we can preliminarily determine the basic conditions of rock burst, so as to prevent rock burst.

\subsection{Article Structure}

The objective of this study is to develop a better understanding of the distribution characteristics of in-situ stress in the Juye mining area, and its application in rock burst control. The organization chart of this paper is as shown in Figure 1.

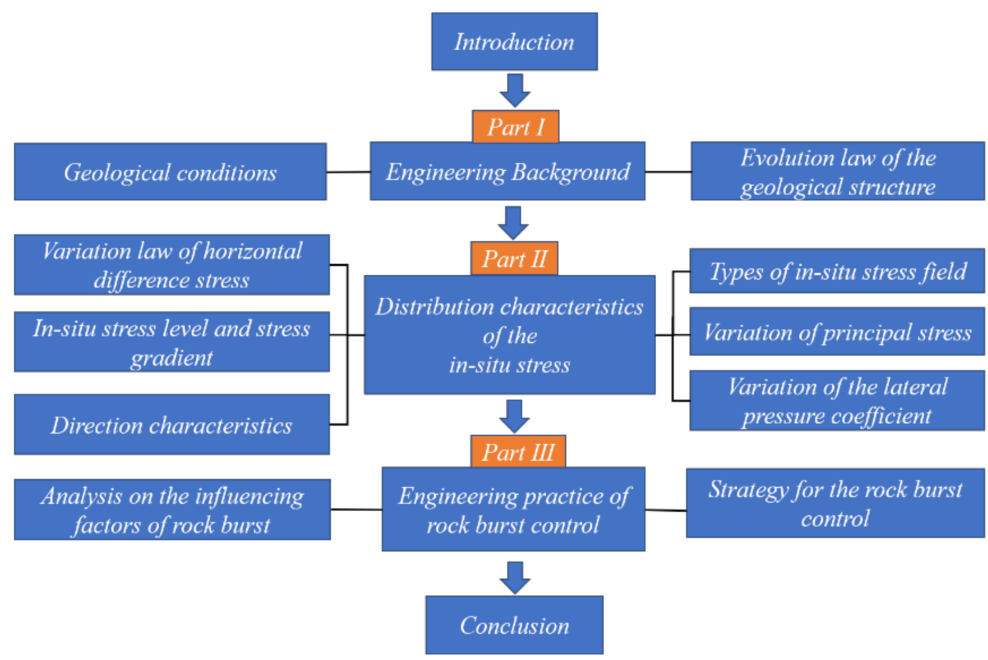

Figure 1. Article organization chart.

This paper is organized as follows: the geological structure characteristics evolution characteristics in the Juye mining area were first presented in Section 1. In Section 2, the 
type and direction of the in-situ stress field were revealed based on the collected in-situ stress data, and the variation law of principal stress, the lateral pressure coefficient, as well as the horizontal difference stress with depth, are discussed in this paper. In Section 3, the design principles of the roadway layout and the anti-impact support were proposed in the Juye mining area, its validity was verified by a field application. The results presented in this paper have important theoretical and practical implications for the exploitation of coal resources, the construction of roadway engineering structures, and the prevention and control of rock burst disasters in the Juye mining area.

\section{Engineering Background}

\subsection{Geological Conditions}

The Juye mining area includes Juye, Jinxiang, Liangbaosi, and other places, with a total area of $2600 \mathrm{~km}^{2}$ and a coal-bearing area of $1210 \mathrm{~km}^{2}$. The total proven coal reserves are 5.571 billion tons. Seven pairs of coal mines are planned and constructed in the Juye mining area, which are the Yuncheng, Guotun, Zhaolou, Xinjulong, Wanfu, Liangbaosi, and Pengzhuang coal mines. The annual coal production is 18 million tons, which effectively solves the energy supply problem in Shandong Province and even East China (Figure 2).

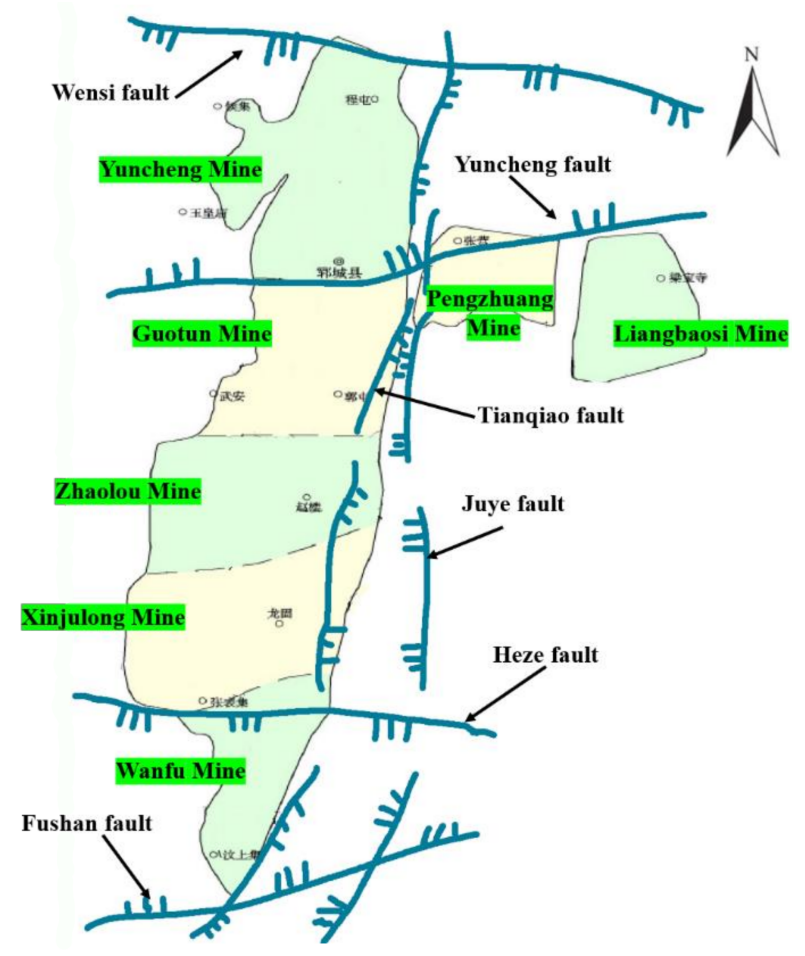

Figure 2. Structural distribution of the Juye mining area.

The strata in the Juye mining area are well distributed from Archean to Cenozoic. From top to bottom, the strata are Quaternary, Neogene, Permian, Carboniferous, and Ordovician. The Quaternary and Neogene strata are mainly composed of clay and sandy clay, with an average deposition thickness of more than $500 \mathrm{~m}$. The Carboniferous Permian stratum is mainly composed of mudstone, sandstone, and coal, which is the coal-bearing stratum in this area. The Ordovician stratum is mainly composed of limestone, dolomite, and marlstone. $3 \#$ coal seam is the main mining coal seam in this area, with an average thickness of $6.6 \mathrm{~m}$ and a buried depth of 700-1300 $\mathrm{m}$.

The Juye mining area is located in the North China plate and the Luxi uplift. It is a fault depression basin with a large number of folds and fault zones. Its main tectonics and its location are shown in Figure 2. The strike of the coalfield is generally close to the north-south (NS) direction, and the coal seam is mainly controlled by the fault zone. The fault zone is distributed in a grid shape, mainly including the Wensi, Yuncheng, Heze, 
Fushan, Tianqiao, and Juye faults. The basic characteristics are listed in Table 1. There is a large number of east-west (EW) trending faults, and most of them are bulges and depressions. The near north-south (NS) direction fault is mainly controlled by the Tianqiao and Liaokao faults. In addition, a large number of north-east (NE) to near north-east (NE) and EW folds are developed in the region, which makes the overall tectonic stress field more complex.

Table 1. Characteristics of the main fault structures in the mining area.

\begin{tabular}{cccc}
\hline Name of Fault Zone & Strike & Dip & Dip Angle \\
\hline Wensi fault & $90-130^{\circ}$ & Southwest & $70-80^{\circ}$ \\
Yuncheng fault & $80-90^{\circ}$ & North & $70-80^{\circ}$ \\
Heze fault & $90-110^{\circ}$ & South & $70-80^{\circ}$ \\
Fushan fault & $70-90^{\circ}$ & South & $45-80^{\circ}$ \\
Juye fault & $180^{\circ}$ & West & $85^{\circ}$ \\
Tianqiao fault & $185-230^{\circ}$ & Southeast & $70^{\circ}$ \\
\hline
\end{tabular}

\subsection{Evolution Law of the Geological Structure in the Juye Mining Area}

The Juye mining area is located to the east of the North China plate, bounded by the LiaoKao fault in the west, the Tan Lu fault in the East, the Qi Guang fault in the north, and the Hefei Basin in the Mesozoic-Cenozoic stratum in the south. In geological history, the Juye mining area has experienced three major tectonic movements: the Indosinian movement in the Triassic stratum, the middle Yanshanian movement in the Mesozoic stratum, and the late Yanshanian movement.

The Indonesian movement formed the strata of the whole North China coal accumulation basin before the Triassic fold uplift and fault movement. The collision of the north and south continental blocks triggered the Paleozoic strata fold and fault movement, forming the east-west (EW)fold and fault. The tectonic stress field in this period was mainly in the south-north (SN) direction, which is the first stage of the development of the tectonic stress field.

In the middle Yanshan period, the north-west (NW) compression weakened with the mantle plastic flow. The lateral tension of the mantle plastic flow and the compression force of the plate edge in the north-west (NW) direction jointly controlled the development of normal faults. The south-north (SN) and east-west (EW) normal faults control the occurrence of coal measure strata in the Juye mining area. In this period, the north-west (NW) tectonic force was the strongest, and the direction of the tectonic stress field was northwest-southeast (NW-SE), which is the second stage of the development of the tectonic force field.

In the late Yanshan period, the mantle stress is replaced by the plate extrusion pressure. The deviation of rock strata was caused by compression action, and thus an arc structure was gradually formed. Then, the stratum was squeezed and uplifted by many different directions of tension and torsion. The direction of the tectonic stress field in this period was mainly north-east (N-E) direction. This is the third stage of the development of the tectonic stress field.

From the above analysis, it can be concluded that the geological structure and in-situ stress field in the Juye mining area are in a state of constant change. From the SN direction in the first tectonic movement to the NW direction in the second tectonic movement and finally to the NNE direction in the third tectonic movement.

\section{Distribution Characteristics of the In-Situ Stress in the Juye Mining Area}

\subsection{Data Sources}

The "recommended method for determining rock stress" was promulgated by the committee on test methods of the international society for rock mechanics in 1987 . They confirmed the following four measurement methods as recommended methods: flat jack method, hydraulic fracturing method, USBM borehole diameter deformation gauge method, 
and CSIRO hollow inclusion strain gauge method. At present, the hollow inclusion stress measurement method is the only method that can measure three-dimensional in-situ stress state. It can eliminate the error caused by temperature, so we choose the hollow inclusion stress relief method for in-situ stress measurement.

An in-situ stress test was conducted in the Guotun and Pengzhuang coal mines from 2018 to 2020, thus acquiring 12 groups of in-situ stress measurement data. In addition, the in-situ stress data of the other five coal mines were collected from the published literatures in recent years. Then, all data sources were optimized by setting a $95 \%$ confidence level. Finally, a total of 66 groups in-situ stress data were selected and used for the analysis.

Some of the selected in-situ stress measurement results are listed in Table 2. Thereinto, $H$ is the buried depth of the measurement point, $\sigma_{v}$ is the vertical principal stress, $\sigma_{H}$ is the maximum horizontal principal stress, and $\sigma_{h}$ is the minimum horizontal principal stress. The overall distribution of the maximum principal stress is displayed in Figure 3.

Table 2. In-situ stress measurement results of some measurement points.

\begin{tabular}{|c|c|c|c|c|c|c|c|}
\hline Number & $\begin{array}{l}\text { Measurement } \\
\text { Point Position }\end{array}$ & $H / m$ & $\sigma_{H}(\mathrm{MPa})$ & $\sigma_{v}(\mathrm{MPa})$ & $\sigma_{h}(\mathbf{M P a})$ & $\begin{array}{c}\text { Direction of } \\
\text { Maximum } \\
\text { Horizontal Stress }\end{array}$ & $\begin{array}{c}\text { Schematic Diagram } \\
\text { of Principal } \\
\text { Stress Direction }\end{array}$ \\
\hline 1 & $\begin{array}{l}\text { Yuncheng Mine } 1300 \\
\text { track lane }\end{array}$ & 829.5 & 30.51 & 23.13 & 17.86 & $273^{\circ}$ & \\
\hline 2 & $\begin{array}{l}\text { Yuncheng Mine } 800 \mathrm{~m} \\
\text { preparation roadway }\end{array}$ & 842.4 & 34.59 & 25.32 & 19.88 & $275^{\circ}$ & \\
\hline 3 & $\begin{array}{l}\text { Pengzhuang Mine } 1309 \\
\text { track lane }\end{array}$ & 721.5 & 17.13 & 11.84 & 9.73 & $128.64^{\circ}$ & \\
\hline 4 & $\begin{array}{l}\text { Pengzhuang Mine West } \\
\text { Wing roadway }\end{array}$ & 537.0 & 15.33 & 12.89 & 7.57 & $136.86^{\circ}$ & \\
\hline 5 & $\begin{array}{l}\text { Zhaolou Mine No. IV } \\
\text { crossing point }\end{array}$ & 860 & 34.72 & 23.27 & 29.98 & $263^{\circ}$ & \\
\hline 6 & $\begin{array}{l}\text { Zhaolou Mine No. XI } \\
\text { crossing point }\end{array}$ & 860 & 36.40 & 24.50 & 21.57 & $255^{\circ}$ & \\
\hline 7 & $\begin{array}{l}\text { Liangbaosi Mine North } \\
\text { Wing track roadway }\end{array}$ & 708 & 20.49 & 18.05 & 9.33 & $330^{\circ}$ & \\
\hline 8 & $\begin{array}{c}\text { Liangbaosi Mine } 3300 \\
\text { track land }\end{array}$ & 826 & 25.04 & 21.47 & 12.74 & $300^{\circ}$ & \\
\hline 9 & $\begin{array}{l}\text { Xinjulong Mine } 1301 \mathrm{~N} \\
\text { track lane }\end{array}$ & 830 & 25.10 & 18.90 & 15.60 & $154^{\circ}$ & \\
\hline 10 & $\begin{array}{l}\text { Xinjulong Mine north } \\
\text { track lane }\end{array}$ & 825 & 31.7 & 18.8 & 14.9 & $125^{\circ}$ & \\
\hline 11 & $\begin{array}{l}\text { Xinjulong Mine } \\
\text { transportation lane }\end{array}$ & 900 & 29.5 & 20.7 & 12.6 & $127^{\circ}$ & \\
\hline 12 & $\begin{array}{l}\text { Xinjulong Mine in the } \\
\text { No. } 1 \text { mining area }\end{array}$ & 750 & 24.9 & 16.9 & 19.8 & $152^{\circ}$ & \\
\hline 13 & $\begin{array}{l}\text { Guotun Mine } 1304 \\
\text { track lane }\end{array}$ & 855.6 & 44.16 & 24.36 & 16.87 & $300^{\circ}$ & \\
\hline 14 & $\begin{array}{l}\text { Guotun Mine } 1301 \\
\text { track lane }\end{array}$ & 842.2 & 31.33 & 20.63 & 17.13 & $294^{\circ}$ & \\
\hline
\end{tabular}


Table 2. Cont.

\begin{tabular}{|c|c|c|c|c|c|c|c|}
\hline Number & $\begin{array}{l}\text { Measurement } \\
\text { Point Position }\end{array}$ & $H / m$ & $\sigma_{H}(\mathrm{MPa})$ & $\sigma_{v}(\mathrm{MPa})$ & $\sigma_{h}(\mathrm{MPa})$ & $\begin{array}{c}\text { Direction of } \\
\text { Maximum } \\
\text { Horizontal Stress }\end{array}$ & $\begin{array}{c}\text { Schematic Diagram } \\
\text { of Principal } \\
\text { Stress Direction }\end{array}$ \\
\hline 15 & Wanfu Coal Mine \#1 & 891.6 & 30.55 & 18.64 & 20.40 & $155.3^{\circ}$ & \\
\hline 16 & Wanfu Coal Mine \#2 & 1024 & 36.43 & 22.05 & 24.50 & $153.4^{\circ}$ & \\
\hline
\end{tabular}

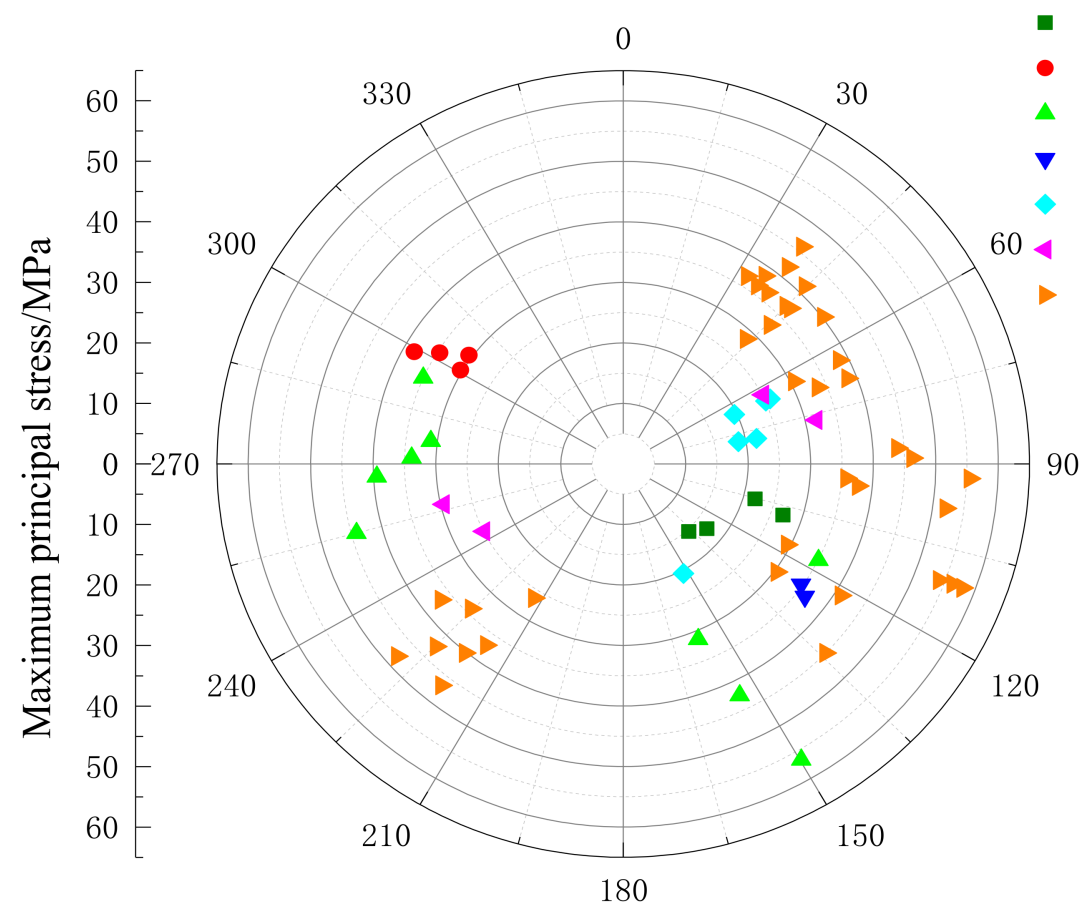

- Pengzhuang mine

- Yuncheng mine

- Guotun mine

> Zhaolou mine

- Liangbaosi mine

4 xinJulong mine

- Wanfu mine

Figure 3. General distribution of principal stress.

\subsection{Analysis of the In-Situ Stress Data}

\subsubsection{Types of In-Situ Stress Field}

Table 3 listed the distribution of the in-situ stress field types with depth changes. It can be seen clearly that there are two types of in-situ stress fields in the Juye mining area, $\sigma_{H}>\sigma_{V}>\sigma_{h}(42.42 \%)$ and $\sigma_{H}>\sigma_{h}>\sigma_{V}(57.57 \%)$. The two types of in-situ stress field changes with the buried depth. In the depth range of less than $900 \mathrm{~m}$, the $\sigma_{\mathrm{H}}>\sigma_{\mathrm{V}}>\sigma_{h}$-type stress state is dominant. Within the more than $900 \mathrm{~m}$ depth, the $\sigma_{H}>\sigma_{h}>\sigma_{v}$-type stress field is dominant. Furthermore, with the increasing of the depth, the vertical principal stress gradually transits from the middle principal stress to the minimum principal stress.

Table 3. Distribution of in-situ stress field types with depth.

\begin{tabular}{cccc}
\hline Depth (m) & \multicolumn{3}{c}{ Number of Different Types of Data } \\
& $\sigma_{H}>\sigma_{v}>\sigma_{h}$ & $\sigma_{H}>\sigma_{h}>\sigma_{v}$ & Total \\
\hline $500-700$ & 1 & 0 & 1 \\
$700-900$ & 26 & 14 & 40 \\
$900-1100$ & 1 & 22 & 23 \\
$>1100$ & 0 & 2 & 2 \\
Total & 28 & 38 & 66 \\
\hline
\end{tabular}

Combined with the relative position of each mine (Figure 2) and its geological structure characteristics, the $\sigma_{H}>\sigma_{v}>\sigma_{h}$-type stress field was found to mainly appear north of the 
Heze fault, but not south of it. The $\sigma_{H}>\sigma_{h}>\sigma_{v}$-type is mainly in the south of the Heze fault. This may be attributed to the tectonic stress caused by the EW-trending Heze and Fushan faults in the south of the mining area.

\subsubsection{Variation of Principal Stress with Depth}

The maximum, minimum, and vertical principal stresses and the corresponding buried depth of each measurement point were plotted in Figure 4. The least-square method was used for linear regression fitting. The fitting results are as follows:

$$
\begin{gathered}
\sigma_{H}=0.04548 H-4.7344\left(R^{2}=0.89382\right) \\
\sigma_{h}=0.04245 H-16.428\left(R^{2}=0.88381\right) \\
\sigma_{v}=0.01377 H+8.4259\left(R^{2}=0.90271\right)
\end{gathered}
$$

where $H$ is the depth (m), and $R^{2}$ is the correlation coefficient.

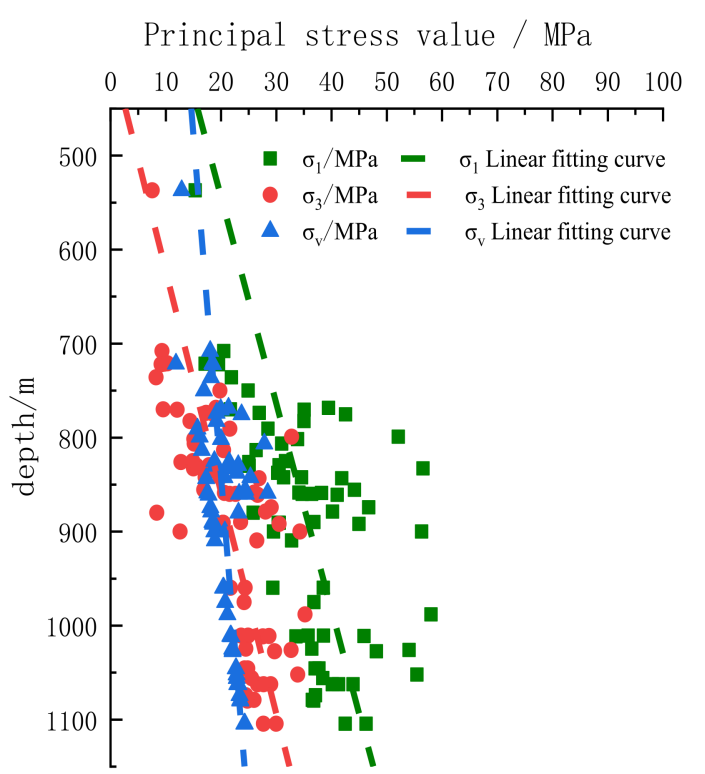

Figure 4. Fitting curve of principal stress with depth.

From Equations (1)-(3), it can be concluded that a good fitting effect was obtained by the three main stress fitting equations with the correlation coefficient $R^{2}$ of greater than 0.88 . It can be also seen in Figure 4 that the principal stress value increases approximately linearly with the depth, and the maximum principal stress is slightly discrete. This may be caused by the differences in the geological structure and rock stratum characteristics in different degrees of the local range.

The in-situ stress fitting results of the Juye mining area were compared with those of the surrounding areas, as shown in Table 4. (All measured data in Table 4 are obtained by hollow inclusion stress relief method). It can be inferred that the variation trend between the Juye mining area and the surrounding areas shows a good agreement on the whole. However, the $\sigma_{H}$ and $\sigma_{h}$ stress gradient changes are relatively large, and the $\sigma_{v}$ is relatively small. This difference also exhibits the complexity and evident regionality of the distribution characteristics of the in-situ stress field in this mining area. 
Table 4. Comparison of the principal stress variations with depth of the Juye mining area and other mining areas.

\begin{tabular}{ccccc}
\hline$\sigma_{H}$ & $\sigma_{h}$ & $\sigma_{v}$ & Region & Source \\
\hline $0.04548 H-4.73$ & $0.04245 H-16.43$ & $\sigma 0.01377 H+8.431$ & Juye mining area & This article \\
$0.0242 H+9.4269$ & $0.0180 H+3.8302$ & $0.0258 H+0.5626$ & Shandong Province & Li et al. [15] \\
$0.0233 H+4.665$ & $0.0162 H+2.100$ & - & North China & Huang et al. [16] \\
\hline
\end{tabular}

\subsubsection{Variation of the Lateral Pressure Coefficient with Depth}

The lateral pressure coefficient is an important characterization of the in-situ stress state. In this paper, the ratios of $\sigma_{H}$ to $\sigma_{v}, \sigma_{h}$ to $\sigma_{v}$, and $\sigma_{(H+h) / 2}$ to $\sigma_{v}$ are denoted as $K_{H}, K_{h}$, and $K_{a v}$. They were used to analyze the variation law of the in-situ stress state with depth. The curve function $\mathrm{K}=\mathrm{a} / \mathrm{H}+\mathrm{b}$ was used for regression fitting, and the fitting results are as follows:

$$
\begin{aligned}
K_{H} & =61.78 / H+1.32 \\
K_{h} & =87.56 / H+0.96 \\
K_{a v} & =117.41 / H+1.41
\end{aligned}
$$

Figure 5a-c shows the fitting curves of three lateral pressure coefficients varying with depth. It can be concluded that the distribution of the $K_{H}$ data is relatively discrete, ranging from 1.02 to 3.22, with an average of 1.74. The distribution of $K_{h}$ and $K_{a v}$ shows a good regularity. The $K_{h}$ value is $0.36-2.03$ with an average of 1.05 , and the $K_{a v}$ is $0.74-2.63$ with an average of 1.39. In general, with increased depth, the values of the three lateral pressure coefficients have a decreasing trend. It can also be inferred that $K_{H}, K_{h}$, and $K_{a v}$ approach $1.32,0.96$, and 1.41, respectively, indicating that the horizontal tectonic stress is dominated in the Juye mining area.

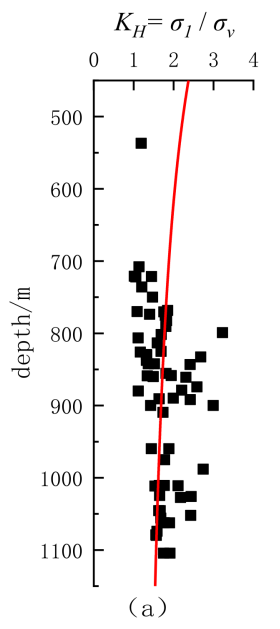

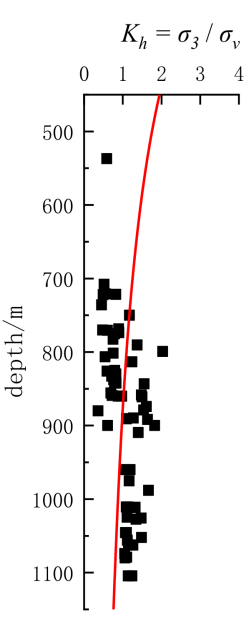

(b)

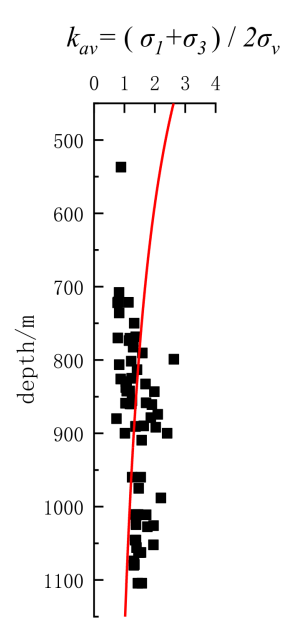

(c)

Figure 5. Fitting curves of the lateral pressure coefficients changing with the depth. (a). Ratio of horizontal stress to vertical stress; (b) Ratio of minimum principal stress to vertical stress; (c) Ratio of average horizontal stress to vertical stress.

\subsubsection{Variation Law of Horizontal Difference Stress with Depth}

The horizontal difference stress $\mu_{d}=\left(\sigma_{1}-\sigma_{3}\right) /\left(\sigma_{1}+\sigma_{3}\right)$ is an important parameter for characterizing the state of crustal failure. In this paper, the non-linear curve $\mu_{d}=a / H+b$ was used to fit the law of $\mu_{d}$ with depth. The fitting curve is shown in Figure 6. The fitting results are as follows:

$$
\mu_{d}=12.23 / H+0.21
$$




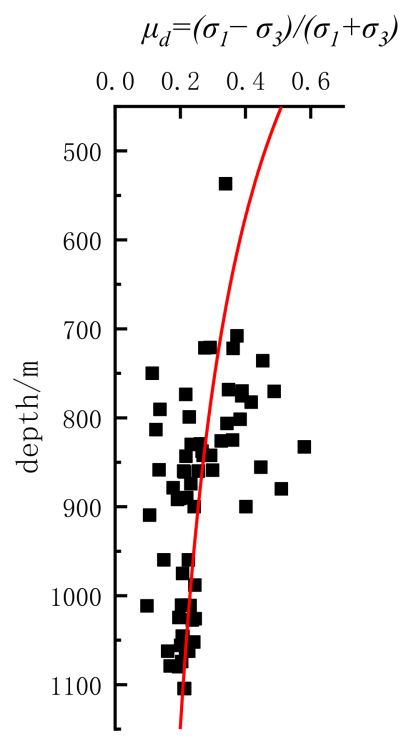

Figure 6. Variation of $\mu \mathrm{d}$ with burial depth.

It can be seen from Figure 6 that the distribution of the $\mu_{d}$ is relatively centralized, reflecting a good fitting effect. The range of $\mu_{d}$ is $0.09-0.58$, with an average of 0.26 , and $73 \%$ of the stresses were $0.20-0.30$. With increased depth, there is a trend approaching 0.2 . Related studies have shown that the formation tends to slip shear failure when the $\mu_{d}$ value exceeds $0.5-0.7$. The $\mu_{d}$ of the Juye mining area is within the $0.09-0.58$, and most of the stresses are less than 0.5 . Thus, it can be inferred that slip failure is not likely to occur in the Juye mining area under the current stress state.

\subsubsection{In-Situ Stress Level and Stress Gradient in the Mining Area}

The number of measurement points of each stress level is shown in Figure 7. According to the in-situ stress level criteria $[17,18]$, there are 50 points with super-high stress (more than $30 \mathrm{MPa}$ ), accounting for $75.75 \%$; 14 points with high stress (18-30 MPa), accounting for $21.21 \%$; 2 points with medium stress (10-18 MPa), accounting for $3.03 \%$.

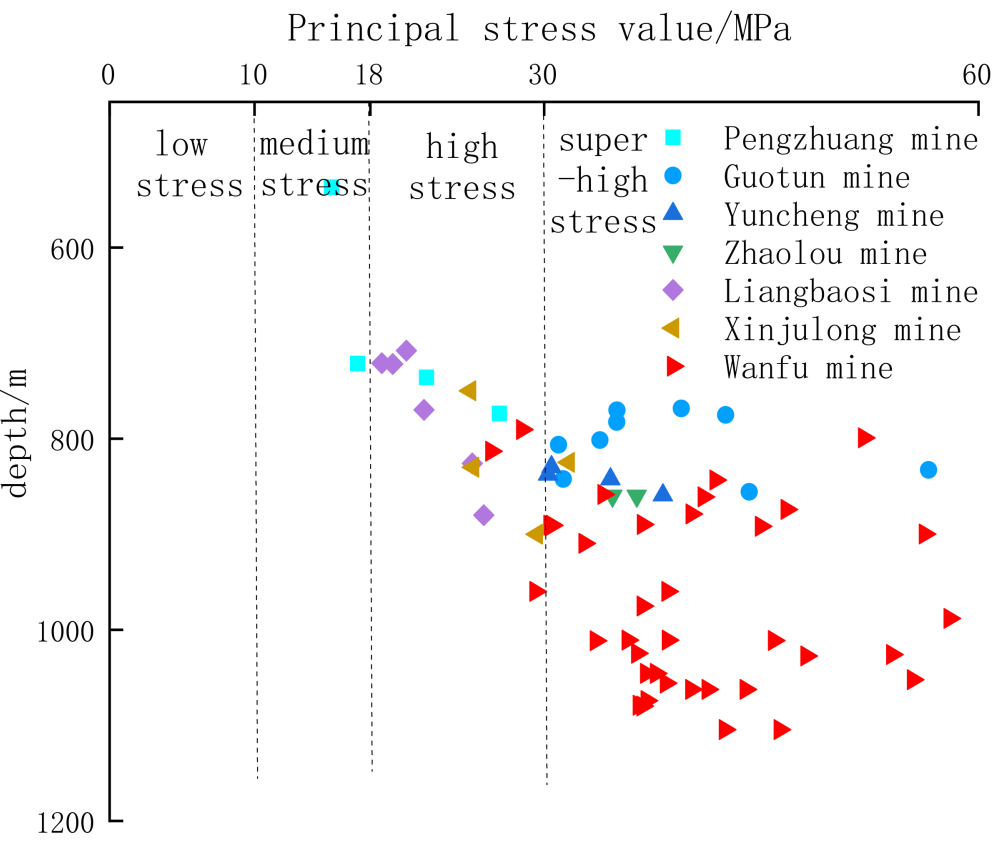

Figure 7. Stress distribution grade of each measurement point. 
The stress gradient of each mine is listed in Table 5. It can be seen that the overall stress gradient value of the mining area is large, and the dispersion is high. Particularly, the stress gradient of the Wanfu and Guotun coal mines exceeds $4.0 \mathrm{MPa} / 100 \mathrm{~m}$, which is caused by the large buried depth and the tectonic stress fields. Therefore, more attention should be paid to engineering problems caused by high in-situ stress in the mining process of deep coal resources in the Juye mining area.

Table 5. Stress gradient values of each mine.

\begin{tabular}{cccc}
\hline Mine Name & $\begin{array}{c}\text { Average } \\
\text { Sounding }(\mathbf{m})\end{array}$ & $\begin{array}{c}\text { Average Maximum } \\
\text { Principal Stress } \mathbf{( M P a})\end{array}$ & $\begin{array}{c}\text { Stress Gradient } \\
\mathbf{( M P a / 1 0 0 ~ m )}\end{array}$ \\
\hline Yuncheng Mine & 842.1 & 33.4 & 3.96 \\
Pengzhuang Mine & 692.0 & 20.3 & 2.93 \\
Liangbaosi Mine & 771.1 & 21.9 & 2.83 \\
Zhaolou Mine & 860.0 & 35.6 & 4.13 \\
Xinjulong Mine & 826.3 & 27.8 & 3.37 \\
Wanfu Mine & 970.9 & 40.3 & 4.15 \\
Guotun Mine & 803.3 & 38.7 & 4.81 \\
\hline
\end{tabular}

\subsubsection{Direction Characteristics of the Maximum Horizontal Principal Stress}

Figure 8 is a rose diagram of the dominant direction of the maximum horizontal principal stress in the Juye mining area. Statistics show that there are 43 measurement points in the northeast-southwest (NE-SW) direction, accounting for $65.15 \%$, and 23 measurement points in the northwest-southeast (NW-SE) direction, accounting for $34.84 \%$. The dominant direction of the maximum horizontal principal stress in the Juye mining area is northeast-southwest (NE-SW), and northwest-southeast (NW-SE) also accounts for a large proportion. This is consistent with the direction of the whole Shandong area [19]

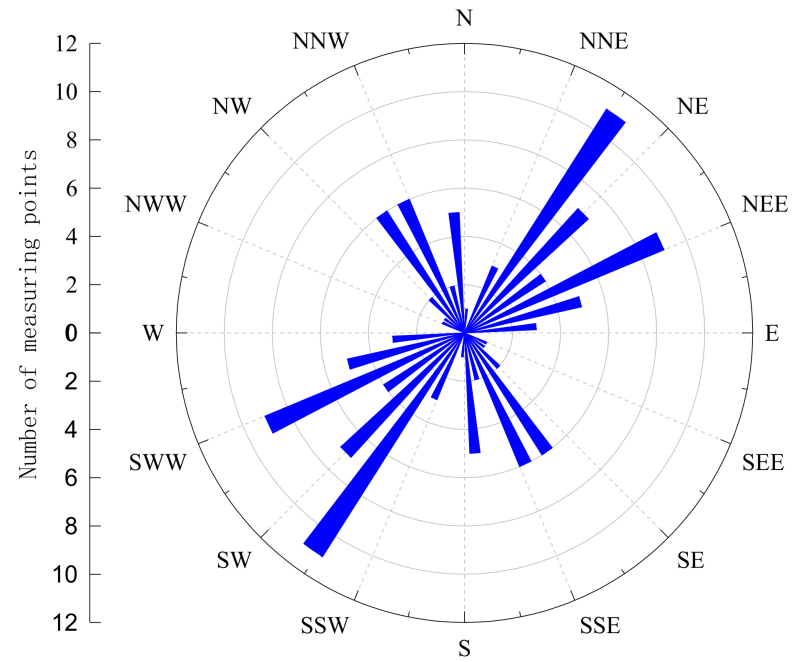

Figure 8. Rose diagram of the maximum principal stress in the mining area.

The maximum horizontal principal stresses in the different mines have various degrees of difference, see Figure 9. In particular, the direction of the maximum horizontal principal stress in the Liangbaosi coal mine presents a certain degree discrete, which is less consistent with the whole Juye mining area. On the whole, the two maximum principal stress directions northeast-southwest (NE-SW), and northwest-southeast (NW-SE) alternate from north to south. The development of composite folds and faults leads to the strata movement from the northwest (NW) to the northeast (NE) and east-west $(\mathrm{E}-\mathrm{W})$, thus resulting in the deflection of the principal stress direction. 


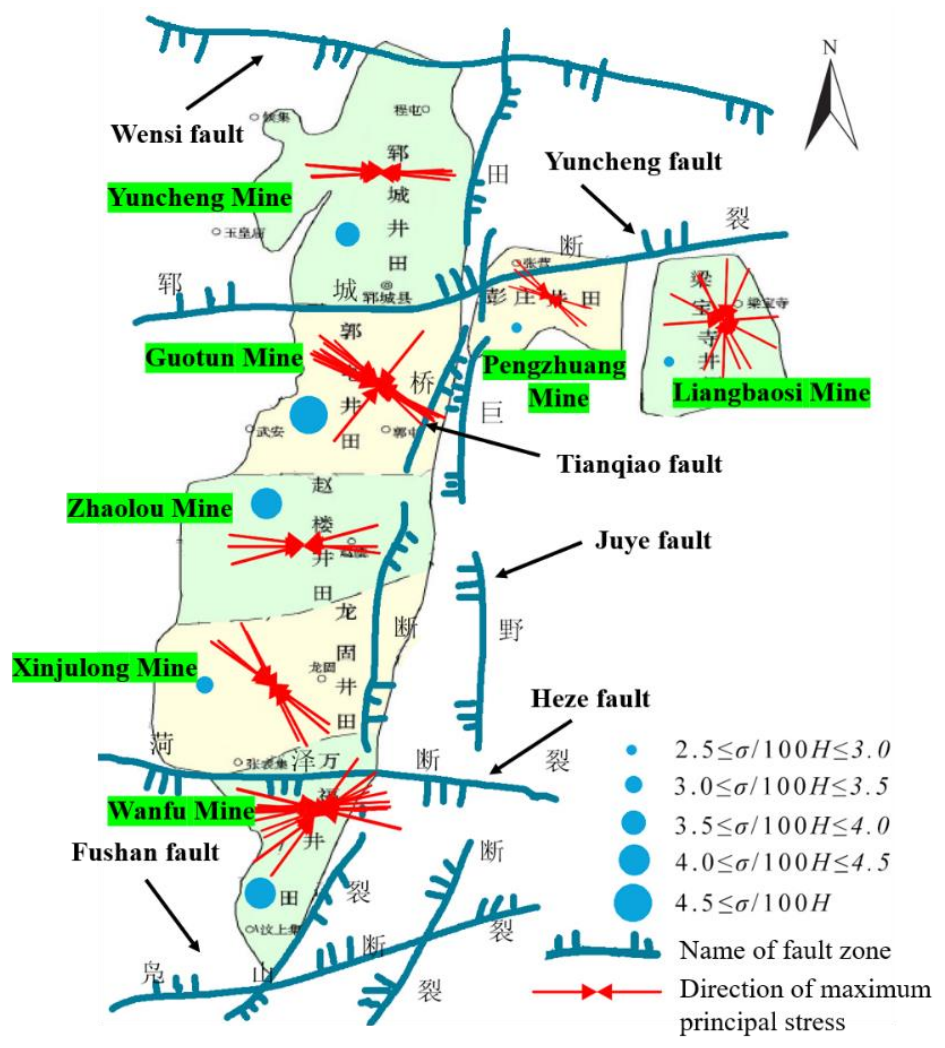

Figure 9. Directional distribution of the maximum horizontal principal stress.

\section{Engineering Practice of Rock Burst Control in the Juye Mining Area}

\subsection{Analysis on the Influencing Factors of Rock Burst}

It has been proved that the near-field static load is the internal cause of rock burst, while the far-field dynamic load is the external cause [20,21]. When the static load level is high, a small dynamic load can also lead to rock burst. The Juye mining area is characterized by a super-large depth and a complex geological structure, which make the stratum itself contain ultra-high static stress with variable direction (as shown in Figures 7-9). Additionally, the stress redistribution process induced by coal mining activities further improves the nearfield static load level of the surrounding rock [22]. Consequently, the probability of rock burst is very high due to the accumulated extremely high static stress. In other words, the high static stress is the fundamental driving force of rock burst in the Juye mining area. Therefore, taking reasonable measures to weaken the high static stress of the rock mass surrounding the mining space is the key to preventing rock burst.

\subsection{Strategy for the Rock Burst Control}

In this paper, a new combined supporting strategy, incorporating optimization of roadway layout, anti-impact support system design, and local reasonable pressure relief, was proposed for the rock burst control. The detailed technology parameters should be determined based on the existing economic and technical conditions, relevant theories, and engineering practice of various mines in the Juye mining area.

\section{(1) Optimization of roadway layout}

The fundamental way of preventing rock burst is optimizing the excavation position and time [23,24]. The following are the specific measures. First, roadways should be excavated along the direction of the maximum principal stress or at an acute angle with it as far as possible. Taking the Zhaolou coal mine as an example, roadways should be arranged along the EW direction as far as possible. Second, for the gob-side entry arranged 
in a single coal seam, it should be excavated along the edge of the stable goaf with a 3-5 m small coal pillar or no-coal-pillar. The roadways should be performed $1.5 \sim 2$ years after the mining of the adjacent panel. Thus, the gob-side entry can be performed in a low-stress environment. Third, the $3 \#$ main coal seam in this area is developed in layers with 20-110 m intervals. Under this condition, the upper layer with a smaller thickness should be exploited first to optimize the stress environment of the lower-layered roadway. Fourth, the roadway layout should avoid large geological structures (fault, fold, collapse column) as far as possible.

\section{(2) Anti-impact support scheme design}

The anti-impact support system is mainly composed of three parts, of which the first part is high-strength anchor bolt, anchor cable, and anchor mesh. The second part is the hydraulic support, which can protect the working face and construction personnel. The third part is the advanced unit support, which can resist the advanced stress brought by the mining of the working face.

Improving the anti-impact performance of the support system is another important measure to rock burst control [25-27]. Based on the theory of collaborative bearing, an anti-impact support system consisting of one-stage high-strength anchor cables, two-stage advanced unit supports, and three-stage hydraulic supports is formed [28,29]. Thereinto, the anchor-bearing structure is the last line of prevention and control of rock burst. It is necessary to scientifically select bolts, cables, and surface protection components to improve its overall impact resistance [30,31].

The details are as follows. First, a high-elongation bolt with a yield strength greater than $500 \mathrm{MPa}$ is selected for the anchor, and a T-shaped steel strip with a high bearing capacity, and a large-area thickened butterfly tray are used at the same time. A steel strand with a $21.8 \mathrm{~mm}$ diameter is used as anchor cable, which is used with a large tray and a thick steel strip. Meanwhile, a double-bubble yielding ring is used to improve the elongation of the anchor cable. The roadway surface is reinforced by a high-strength anti-impact woven mesh. Second, a walking hydraulic support is used for support within $50 \mathrm{~m}$ ahead of the working face, and a unit support is used for support within $50-120 \mathrm{~m}$. Compared with the conventional single hydraulic support, advanced unit support and hydraulic support are characterized by a large support area and a high bearing capacity. When a rock burst occurs, they can maintain the roadway space and reduce the casualties.

\section{(3) Local pressure relief measures}

During panel retreating, local high stress concentrations occurred frequently in the two ribs of the roadway, which may result in rock burst accidents. Therefore, it is necessary to take the combination pressure relief measures of large-diameter drilling and blasting to prevent rock bursts from occurring [32,33]. Under normal conditions, large-diameter drilling with reasonable drilling spacing, diameter, and depth design is used to relieve pressure. In the case of stress, concentration cannot be relieved by large-diameter drilling, blasting measures should be performed to release the high stress.

\subsection{Engineering Practice}

This paper provides an illustrative, detailed algorithm on how to implement the suggested method to control the rockburst based on measured in-situ stresses. As shown in Figure 10, first conduct in-situ stress measurement, and then obtain stress conditions according to the measurement results. The roadway layout is guided according to the stress direction, and the roadway support strength is designed according to the stress value. Combined with geological, engineering, and technical conditions, a rock burst prevention and control system is formed. Finally, the engineering effect is analyzed. When the stability does not meet the requirements, the roadway support design is carried out again until the stability requirements are met. So far, the final permanent support system is formed. The following will be explained in combination with specific examples. 


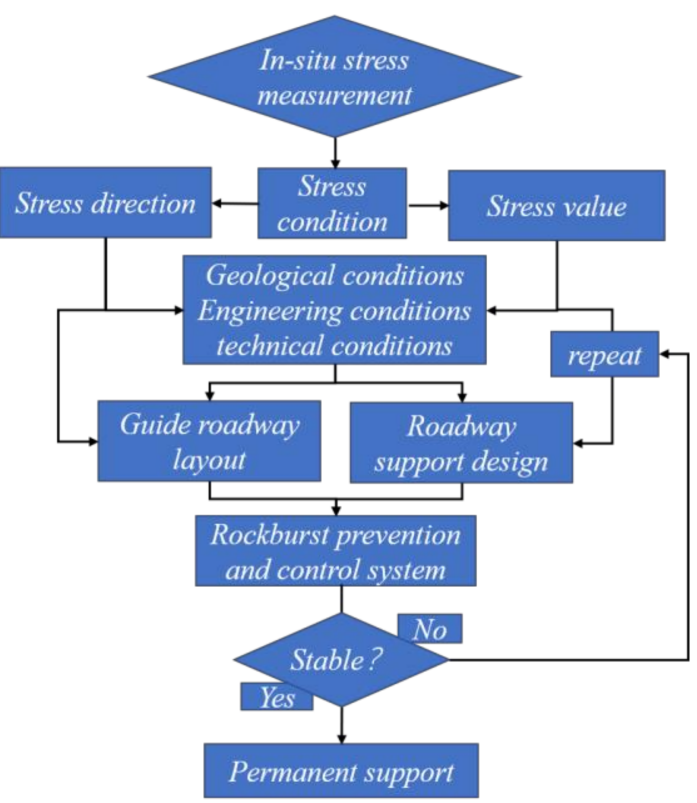

Figure 10. Algorithm flow chart.

\subsubsection{Engineering Geology of the Test Site}

The test site is located in the 7302 working face of the Zhaolou coal mine, with an average depth of $860 \mathrm{~m}$. The north of the working face is the goaf of the no. 5 mining district and the large fault. The average thickness of the coal seam is $6.0 \mathrm{~m}$. The roof is the sandstone with an average thickness of $19.48 \mathrm{~m}$, while the floor is the sandstone with an average thickness of $9.1 \mathrm{~m}$.

According to the in-situ stress measurement results of the Zhaolou coal mine, the average maximum principal stress is $36.2 \mathrm{MPa}$, the average vertical stress is $27.61 \mathrm{MPa}$, and the minimum principal stress is $22.12 \mathrm{MPa}$. The maximum horizontal principal stress is in the $\mathrm{W} 4^{\circ} \mathrm{S}$ direction (near east-west direction).

\subsubsection{Roadway Layout and Support Scheme Design}

Considering the specific engineering geological conditions and construction conditions of the 7302 working face, an optimization design scheme is implemented. The angle between the direction of excavation and the maximum principal stress is set to 18 degrees $\left(\mathrm{W} 22^{\circ} \mathrm{S}\right)$. The roadway is driven along the coal seam floor, with a trapezoidal section shape, which is $4.0 \mathrm{~m}$ high, $4.8 \mathrm{~m}$ wide at the top, $5.8 \mathrm{~m}$ wide at the bottom, and the area is $22.5 \mathrm{~m}^{2}$. The specific layout of the roadway is shown in Figure 11.

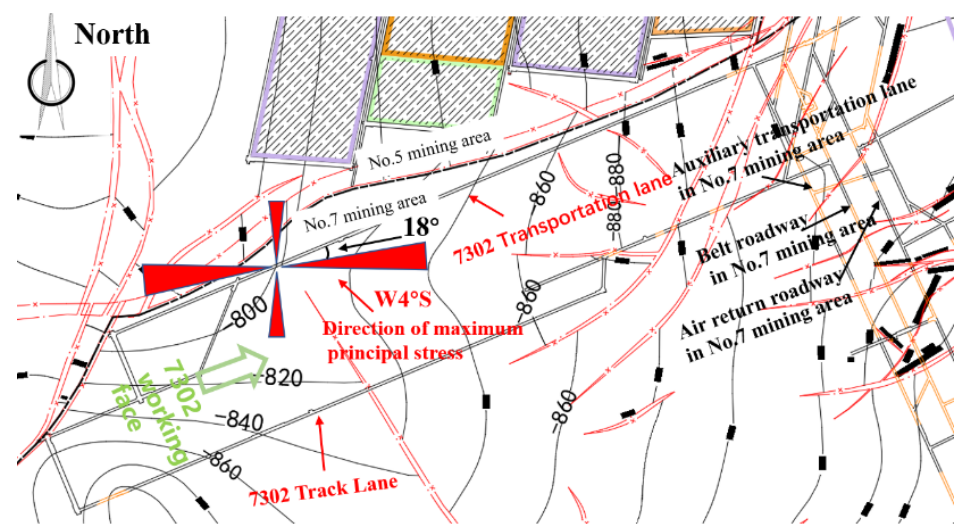

Figure 11. General layout of the roadway at the working face 7302. 
The anti-impact support system of the one-stage high-strength anchor cable, two-stage advanced unit support, and three-stage hydraulic support scheme are adopted. The specific support parameters are as follows.

1. Six high-strength threaded steel bolts with a $22 \mathrm{~mm}$ diameter, a $2400 \mathrm{~mm}$ length, and $500 \mathrm{MPa}$ tensile strength were used in the roof. The bolts were installed with a spacing of $850 \mathrm{~mm} \times 800 \mathrm{~mm}$. The bolts are connected to each other by a T-shaped steel belt with a $10 \mathrm{~mm}$ thickness, $140 \mathrm{~mm}$ width, and $4800 \mathrm{~mm}$ length. In addition, three high-strength anchor cables with a $22 \mathrm{~mm}$ diameter and a $6.2 \mathrm{~m}$ length are used in the roadway roof. The row spacing of the anchor cables is $1600 \mathrm{~mm}$, and they are connected by a three-hole $29 \mathrm{U}$ steel bar with a $4400 \mathrm{~mm}$ length. An FZJ-R1/2 doublebubble yielding ring is installed at the tail of each anchor cable.

2. Six left-handed full-threaded bolts with $20 \mathrm{~mm}$ in diameter and $2500 \mathrm{~mm}$ in length were installed with a spacing of $850 \mathrm{~mm} \times 800 \mathrm{~mm}$ in the two ribs of the roadway. Two 1900-mm-long narrow steel strips were used for bolts connection. Three highstrength anchor cables with a $22 \mathrm{~mm}$ diameter and a $6200 \mathrm{~mm}$ length were added to the non-mining side. The spacing of the anchor cables is $1200 \mathrm{~mm} \times 1600 \mathrm{~mm}$. The 18 -channel steel anchor cable beam with a size of $3000 \times 1600 \times 1200 \mathrm{~mm}$ is used for cables connection. The specific support scheme is shown in Figure 12.

3. Five groups of ZT115200/25/45 hydraulic supports were used within $50 \mathrm{~m}$ ahead of the working face, and ZJC3078/32/45D unit supports were used within 50-120 m. The overall length of the advance support should not be less than $120 \mathrm{~m}$.

4. Large-diameter boreholes were used for pressure relief in the two sides of the roadway in the medium-strong impact risk area. The hole diameter is $150 \mathrm{~mm}$, depth is $20 \mathrm{~m}$, and the hole spacing is $1.5-2 \mathrm{~m}$ and $2-2.5 \mathrm{~m}$, respectively; and the height between the boreholes and the floor is $1.2-1.5 \mathrm{~m}$. The boreholes are perpendicular to the coal wall. The layout of the boreholes is shown in Figure 13.

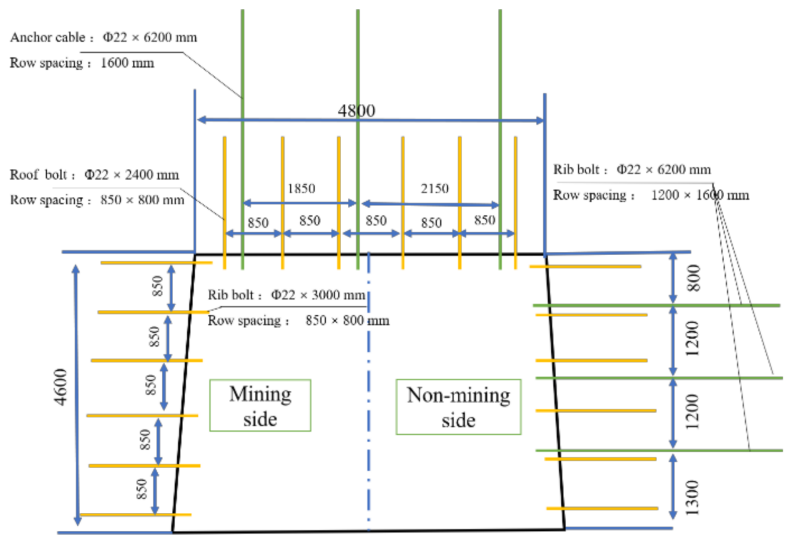

Figure 12. Support scheme of the working face 7302.

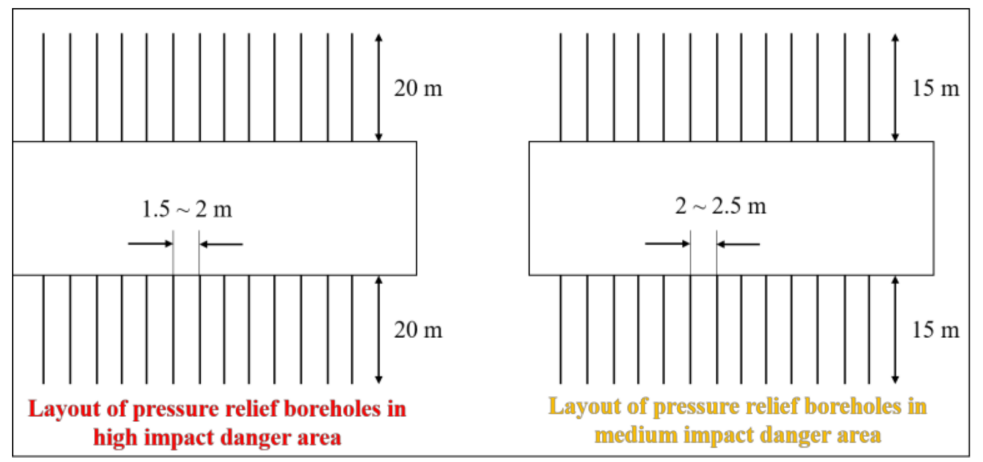

Figure 13. Schematic diagram of the layout of the drilling hole. 


\subsubsection{Analysis of the Engineering Effect}

After the use of the new roadway layout and support scheme, the deformation of two sides and the roof were within the control range. The average roof subsidence was $200 \mathrm{~mm}$, the two ribs' convergence was $360 \mathrm{~mm}$, and there was no floor heave and an obvious dynamic behavior event.

During the panel retreat period, the deformation of the roadway increased slightly, and the overall deformation is always at a low level. The roadway could meet the requirements of the ventilation and normal mining of the working face. The field support effect is shown in Figure 14.

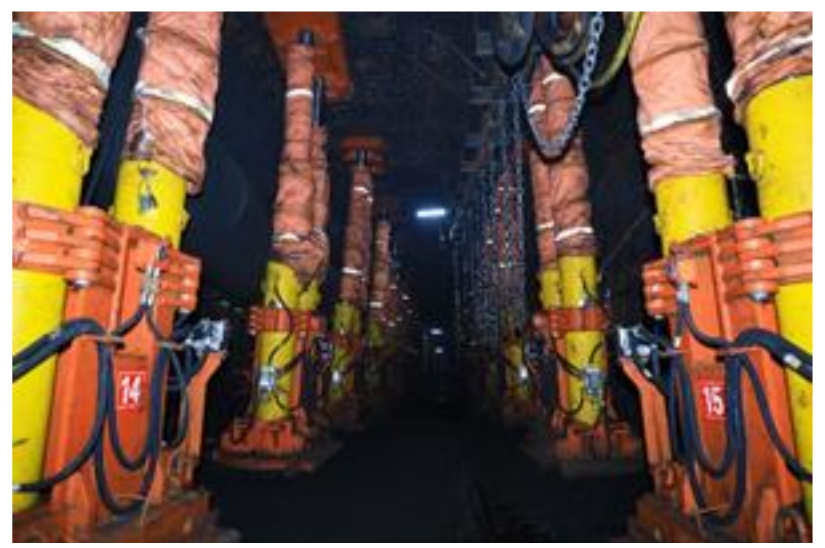

Figure 14. Support effect of the roadway surrounding rock.

\section{Conclusions}

This paper mainly focuses on the distribution law of in-situ stress field in the Juye mining area, and the specific control measures for rock burst prevention are presented. The main conclusions are as follows:

(1) The main tectonic evolution law of the in-situ stress field is from the north-south (NS) direction to the northwest-southeast (NW-SE) direction and finally to the northeastsouthwest (NE-SW) direction in the Juye mining area.

(2) The two types of the in-situ stress field in the Juye mining area are $\sigma_{H}>\sigma_{v}>\sigma_{h}$ and $\sigma_{H}>\sigma_{h}>\sigma_{v}$. The average stress gradient is $3.05 \mathrm{MPa} / 100 \mathrm{~m}$. The dominant direction of the maximum horizontal principal stress is northeast-southwest (NE-SW), but northwest-southeast (NW-SE) also accounts for a large proportion. The discreteness of the in-situ stress types and directions is mainly caused by a large number of fault zones in the Juye mining area and their complex tectonic movements.

(3) The lateral pressure coefficient $K_{H}, K_{h}$, and $K_{a v}$ approach $1.32,0.96$, and 1.41, respectively. The range of $\mu_{d}$ is $0.09-0.58$, thus, it can be inferred that slip failure is not likely to occur in the Juye mining area under the current stress state.

(4) The superpositions of high static and mining stresses lead to the rock burst disasters in the Juye mining area, and the high static stress is the fundamental driving force of rock burst. The key to preventing rock burst is to weaken the high stress in the surrounding rock.

(5) A new combined supporting strategy, incorporating optimization of roadway layout, anti-impact support system design, and local reasonable pressure relief, was proposed for the rock burst control. The anti-impact support system includes a onestage high-strength anchor cable, two-stage advanced unit support, and three-stage hydraulic support. 


\begin{abstract}
Author Contributions: The author G.Z. sorted out the ideas of the full paper and completed the writing of the abstract and introduction. Y.L. and X.M. has completed the analysis of the law of in-situ stress distribution and the engineering background. G.T., L.W. and C.Z. wrote the Engineering practice of rock burst control in the Juye mining area. H.Z. and Z.Q. carried out the field test. Data curation and analysis, H.G. All authors have read and agreed to the published version of the manuscript.

Funding: This study was supported by the National Natural Science Foundation of China (No.51904164), Opening Foundation of State Key Laboratory of Mining Response and Disaster Prevention and Control in Deep Coal Mines (SKLMRDPC20KF05).
\end{abstract}

Institutional Review Board Statement: Not applicable.

Informed Consent Statement: Not applicable.

Data Availability Statement: The data used to support the findings of this study are included in the article.

Conflicts of Interest: The authors declare that they have no conflict of interest.

\title{
References
}

1. Bai, T.; Yang, H.; Chen, X.-B.; Zhang, S.-C.; Jin, Y.-S. In-situ monitoring and reliability analysis of an embankment slope with soil variability. Geomech. Eng. 2020, 3, 261-273.

2. Bednarek, L.; Majcherczyk, T. An analysis of rock mass characteristics which influence the choice of support. Geomech. Eng. 2020, 21,371-377.

3. Bandyopadhyay, K.; Mallik, J.; Ghosh, T. Dependence of fluid flow on cleat aperture distribution and aperture-length scaling: A case study from Gondwana coal seams of Raniganj Formation, Eastern India. Int. J. Coal. Sci. Technol. 2020, 7, 133-146. [CrossRef]

4. Xing, P.-J.; Mclennan, J.; Moore, J. In-situ stress measurements at the utah frontier observatory for research in geothermal energy (forge) site. Energies 2020, 13, 5842. [CrossRef]

5. Pan, Y.-S.; Dai, L.-P.; Li, G.-Z.; Li, Z.-H. Theoretical research and application of rock burst roadway support in mine. J. China Coal Soc. 2021, 46, 112-122.

6. Brooke-Barnett, S.; Flottmann, T.; Paul, P.K.; Busetti, S.; Hennings, P.; Reid, R.; Rosenbaum, G. Influence of basement structures on in situ stresses over the Surat Basin, southeast Queensland. J. Geophys. Res. Solid Earth 2015, 120, 4946-4965. [CrossRef]

7. Das, A.J.; Mandal, P.K.; Paul, P.S.; Sinha, R.K. Generalised analytical models for the strength of the Inclined as well as the flat coal pillars using rock mass failure criterion. Rock Mech. Rock Eng. 2019, 52, 3921-3946. [CrossRef]

8. Cai, M.-F.; Guo, Q.-F.; Li, Y.; Du, Z.-F.; Liu, J.-H. Geostress measurement and its application in pingmei mine. Chin. J. Eng. 2013, 11, 1399-1406.

9. Kang, H.-P.; Jiang, T.-M.; Zhang, X.; Yan, L.-X. Research and application of in-situ stress field in Jincheng mining area. Chin. J. Rock Mech. Eng. 2009, 28, 1-8.

10. Wang, Y.-C.; Jing, H.-W.; Chen, K.-F.; Wei, L.-Y. Research on in-situ stress distribution and spatial zoning in Pingdingshan mining area. Chin. J. Rock Mech. Eng. 2014, 33, 2620-2627.

11. Chen, J.-H.; Liu, P.; Zhao, H.-B.; Zhang, C.; Zhang, J.-W. Analytical studying the axial performance of fully encapsulated rock bolts. Eng. Fail. Anal. 2021, 128, 1-16. [CrossRef]

12. Salmachi, A.; Rajabi, M.; Wainman, C.; Mackie, S.; Mccabe, P.; Camac, B.; Clarkson, C. History, geology, in situ stress pattern, gas content and permeability of coal seam gas basins in australia: A review. Energies 2021, 14, 2651. [CrossRef]

13. Sun, Y.; Zuo, J.; Karakus, M.; Liu, L.; Zhou, H.; Yu, M. A New Theoretical Method to Predict Strata Movement and Surface Subsidence Due to Inclined Coal Seam Mining. Rock Mech. Rock Eng. 2021, 54, 2723-2740. [CrossRef]

14. Shen, W.-L.; Shi, G.-C.; Wang, Y.-G.; Bai, J.-B.; Zhang, R.-F.; Wang, X.-Y. Tomography of the dynamic stress coefficient for stress wave prediction in sedimentary rock layer under the mining additional stress. Int. J. Min. Sci. Technol. 2021, 31, 653-663. [CrossRef]

15. Li, P.; Guo, Q.-F.; Liu, H.-T.; Jiang, X.-Q. Analysis on the characteristics of current in-situ stress field and stress accumulation level in Shandong Province. Chin. J. Rock Mech. Eng. 2017, 36, 2220-2231.

16. Huang, L.-Y.; Yang, S.-X.; Cui, X.-F.; Chen, Q.-C.; Yao, R. Analysis of characteristics of measured stress and stability of faults in North China. Chin. J. Geophys. 2013, 34, 204-213.

17. Cheng, Y.M.; Wang, J.A.; Xie, G.X.; Wei, W.B. Three-dimensional analysis of coal barrier pillars in tailgate area adjacent to the fully mechanized top caving mining face. Int. J. Rock Mech. Min. Sci. 2010, 47, 1372-1383. [CrossRef]

18. Han, H.-X.; Yin, S.-D. Determination of in-situ stress and geomechanical properties from borehole deformation. Energies 2018, 11, 131. [CrossRef]

19. Yang, J.-C.; Liu, K.-W.; Li, X.-D.; Liu, Z.-X. Stress initialization methods for dynamic numerical simulation of rock mass with high in-situ stress. J. Cent. South Univ. 2020, 27, 3149-3162. [CrossRef] 
20. Han, Z.-H.; Zhou, J.; Zhang, L.Q. Influence of grain size heterogeneity and in-situ stress on the hydraulic fracturing process by pfc2d modeling. Energies 2018, 11, 1413. [CrossRef]

21. Pan, J.-F.; Ning, Y.; Lan, H.; Du, T.-T.; Peng, Y.-W. Starting theory of rock burst in coal mining. Chin. J. Rock Mech. Eng. 2012, 31, 586-596.

22. Jepson, G.; King, R.C.; Holford, S.; Bailey, A.H.E.; Hand, M. In situ stress and natural fractures in the Carnarvon Basin, North West Shelf, Australia. Explor. Geophys. 2019, 50, 514-531. [CrossRef]

23. Chen, S.J.; Ren, M.Z.; Wang, F.; Yin, D.W.; Chen, D.H. Mechanical properties and failure mechanisms of sandstone with pyrite concretions under uniaxial compression. Geomech. Eng. 2020, 22, 385-396.

24. Zhang, D.-Q.; Yang, P.; Wu, J.-Y.; Zhao, J.; Chen, Y.-A. Preparation of defect free ceramic/Ti composite membranes by surface modification and in situ oxidation. J. Cent. South Univ. 2019, 26, 3295-3304. [CrossRef]

25. Yi, K.; Liu, Z.-H.; Lu, Z.G.; Zhang, J.-W.; Dong, S.-Y. Effect of axial in-situ stress in deep tunnel analysis considering strain softening and dilatancy. Energies 2020, 13, 1502. [CrossRef]

26. Shabanimashcool, M.; Li, C.C. Analytical approaches for studying the stability of laminated roof strata. Int. J. Rock Mech. Min. Sci. 2015, 79, 99-108. [CrossRef]

27. Mohammed, M.M.; Roslan, H.; Firas, S. Assessment of rapid impact compaction in ground improvement from in-situ testing. $J$. Cent. South Univ. 2013, 20, 786-790. [CrossRef]

28. Zhang, G.-C.; Zang, C.-W.; Chen, M.; Tao, G.-Z.; Li, Y.; Hou, W.-H.; Weng, H.-Z.; Zhao, D.-S. Ground response of entries driven adjacent to a retreating longwall panel. Int. J. Rock Mech. Min. Sci. 2021, 138, 10-17.

29. Zhang, G.-C.; He, F.-L.; Jia, H.-G.; Lai, Y.-H. Analysis of gateroad stability in relation to yield pillar size: A case study. Rock Mech. Rock Eng. 2017, 50, 1263-1278. [CrossRef]

30. Zhang, G.-C.; Wen, Z.-J.; Liang, S.-J.; Tan, Y.-L.; Tian, L.; Zhao, Y.-Q.; Zhao, D.-S. Ground Response of a Gob-side Entry in a Longwall Panel Extracting 17 m-Thick Coal Seam: A Case Study. Rock Mech. Rock Eng. 2020, 53, 497-516. [CrossRef]

31. Chen, J.-H.; Li, D.-Q. Numerical simulation of fully encapsulated rock bolts with a tri-linear constitutive relation. Tunn. Undergr. Space Technol. 2022, 120,1-13. [CrossRef]

32. Li, X.-P.; Zhang, G.-C.; Tao, G.-Z.; Wang, C.; Cao, H.-X.; Zhao, X.-P.; Yan, X.-Y.; Shen, S.-B.; Zhou, G.-L. Ground Behaviors Analysis of a Stope Covered by the Thin Bedrock and Large-Thick Alluvium: A Case Study. Shock. Vib. 2022, 21, 1-14. [CrossRef]

33. Smith, J.-A. Analysis of the influence of groundwater and the stress regime on bolt behaviour in underground coal mines. Int. J. Coal. Sci. Technol. 2019, 6, 286-300. [CrossRef] 